\title{
Vascular endothelial growth factor A polymorphisms are associated with increased risk of coronary heart disease: a meta-analysis
}

\author{
Yafeng Wang ${ }^{1, *}$, Qiuyu Huang ${ }^{2, *}$, Jianchao Liu ${ }^{3}$, Yanan Wang ${ }^{4}$, Gongfeng Zheng ${ }^{1}$, \\ Ling Lin ${ }^{5}$, Hui Yu', Weifeng Tang ${ }^{3}$ and Ziyang Huang ${ }^{1}$ \\ ${ }^{1}$ Cardiovascular Department, The Second Clinical Medical College of Fujian Medical University, Quanzhou, Fujian, China \\ 2 Department of Cardiac Surgery, Union Hospital, Fujian Medical University, Fuzhou, Fujian, China \\ ${ }^{3}$ Department of Cardiothoracic Surgery, Affiliated People's Hospital of Jiangsu University, Zhenjiang, Fujian, China \\ ${ }^{4}$ Department of Function, Agribusiness Hospital of Xishuangbanna, Jinghong, Yunnan, China \\ ${ }^{5}$ Rheumatism Department, The Second Clinical Medical College of Fujian Medical University, Quanzhou, Fujian, China \\ ${ }^{6}$ Department of Abdominal Surgery, Fujian Medical University Cancer Hospital, Fuzhou, Fujian, China \\ * These authors have contributed equally to this work \\ Correspondence to: Ziyang Huang, email: huangziyang_2014@126.com \\ Weifeng Tang, email: twf001001@126.com \\ Keywords: VEGFA, coronary heart disease, susceptibility, polymorphism, meta-analysis \\ Received: January 02, $2017 \quad$ Accepted: February 08, $2017 \quad$ Published: February 20, 2017
}

Copyright: Wang et al. This is an open-access article distributed under the terms of the Creative Commons Attribution License (CC-BY), which permits unrestricted use, distribution, and reproduction in any medium, provided the original author and source are credited.

\section{ABSTRACT}

Coronary heart disease (CHD) is a common complex disease resulting from the interaction of multiple environmental and genetic factors. To assess the potential relationship of vascular endothelial growth factor (VEGFA) rs699947 C>A, rs3025039 C >T and rs2010963 G>C polymorphisms with CHD risk, a comprehensive metaanalysis was conducted. A systematic search of EMBASE and PubMed online database for publications on VEGFA polymorphisms and risk of CHD was carried out. Crude Odds ratios (ORs) with their $95 \%$ confidence intervals (CIs) were calculated to determine the association. A total of ten publications including 22 trails involving 2097 cases and 2867 controls were included in our pooled analysis. Overall, results of the present meta-analysis demonstrated a significant association between VEGFA rs699947 C>A polymorphism and an increased risk of CHD. After stratifying by ethnicity and CHD type, the association was also obtained. A significant association between VEGFA rs3025039 C>T polymorphism and risk of CHD was also found. For VEGFA rs2010963 G $>$ C polymorphism, the polymorphism was associated with MI risk. In conclusion, our findings suggest that VEGFA rs699947 C>A, rs3025039 C>T and rs2010963 G >C polymorphisms are risk factors for CHD. In the future, large sample size and welldesigned epidemiologic studies are needed to confirm these conclusions.

\section{INTRODUCTION}

Coronary heart disease (CHD) is one of the leading causes of mortality and morbidity worldwide $[1,2]$. Besides environmental risk factors (e.g. smoking, drinking, and sedentary lifestyle et al.), genetic factors, such as single-nucleotide polymorphisms (SNPs), may play prominent roles in the development of CHD [3].
Vascular endothelial growth factor (VEGFA) is a glycoprotein molecule generated by the vascular endothelium, retinal pigment epithelium, pericytes, $\mathrm{T}$ cells and macrophages et al [4]. VEGFA, one of the most potent mitogens, acts as an important promoter of angiogenesis in both lymphogenesis and angiogenesis $[5,6]$. It was reported that inflammation and neovascularization in atheromatous plaques might be mediated by VEGFA 
Table 1: Characteristics of the eligible studies in the meta-analysis

\begin{tabular}{|c|c|c|c|c|c|c|c|}
\hline study & year & country & ethnicity & CHD type & $\begin{array}{l}\text { No. of cases/ } \\
\text { controls }\end{array}$ & Genotype Method & polymorphisms \\
\hline Han et al. & 2015 & China & Asians & coronary heart disease & $144 / 150$ & MALDI-TOF MS & rs3025039 C $>$ T and rs2010963 G>C \\
\hline Moradzadegan et al. & 2015 & Iran & Caucasians & coronary heart disease & $141 / 369$ & PCR-RFLP & rs $2010963 \mathrm{G}>\mathrm{C}$ \\
\hline Gu et al. & 2013 & China & Asians & coronary heart disease & $435 / 480$ & MALDI-TOF MS & $\begin{array}{l}\text { rs699947 C>A, rs3025039 C>T and } \\
\text { rs2010963 G>C }\end{array}$ \\
\hline Cui et al. & 2013 & China & Asians & coronary heart disease & $242 / 253$ & MALDI-TOF MS & $\begin{array}{l}\text { rs699947 C>A, rs3025039 C }>\text { T and } \\
\text { rs2010963 G }>C\end{array}$ \\
\hline Amoli et al. & 2012 & Iran & Caucasians & coronary heart disease & $50 / 50$ & ARMS-PCR & rs699947 C>A \\
\hline Guerzoni et al. & 2009 & Brazil & Caucasians & coronary heart disease & $145 / 99$ & PCR-SSCP & rs699947 C>A \\
\hline Douvaras et al. & 2009 & Greece & Caucasians & myocardial infarction & $102 / 98$ & PCR-RFLP & rs $3025039 \mathrm{C}>\mathrm{T}$ and rs2010963 G>C \\
\hline Kangas-Kontio et al. & 2009 & Finland & Caucasians & myocardial infarction & $215 / 218$ & TaqMan & $\begin{array}{l}\text { rs699947 C>A, rs3025039 C }>\text { T and } \\
\text { rs2010963 G }>C\end{array}$ \\
\hline Kangas-Kontio et al. & 2009 & Finland & Caucasians & myocardial infarction & $36 / 263$ & TaqMan & $\begin{array}{l}\text { rs699947 C>A, rs3025039 C > T and } \\
\text { rs2010963 G>C }\end{array}$ \\
\hline Biselli et al. & 2008 & Brazil & Caucasians & coronary heart disease & $175 / 108$ & PCR-SSCP & rs699947 C $>$ A and rs3025039 C $>\mathrm{T}$ \\
\hline Petrovic et al. & 2006 & Slovenia & Caucasians & myocardial infarction & $143 / 228$ & PCR-RFLP & rs $2010963 \mathrm{G}>\mathrm{C}$ \\
\hline
\end{tabular}

Abbreviations: MALDI-TOF MS, Matrix-Assisted Laser Desorption/Ionization Time of Flight Mass Spectrometry; ARMSPCR, Amplification Refractory Mutation System-Polymerase Chain Reaction; PCR-SSCP, Polymerase Chain Reaction-SingleStrand Conformational Polymorphism; PCR-RFLP, Polymerase Chain Reaction -Restriction Fragment Length Polymorphism.

[7]. Previous study also found that increased plasma VEGFA levels in CHD patients may indicate the severity of coronary lesion, and it may be adopted as an indicator of the need for revascularization $[8,9]$. These results suggested that VEGFA might be involved in the development of CHD.

The VEGF gene, also named as vascular permeability factor, is located on chromosome $6 \mathrm{p} 21.3$ and contains eight exons [10]. VEGF family consists of VEGFA, VEGFB, VEGFC, VEGFD, VEGFE, VEGFF and placental growth factor. The human VEGFA gene is very polymorphic (http://www.ncbi.nlm.nih.gov/SNP). And the variants of VEGFA gene may influence the expression between individuals [11]. Functional studies indicated that a number of variants in VEGFA gene were correlated with the level of mRNA and protein expression $[12,13]$. Three single nucleotide polymorphisms (SNPs), VEGFA rs699947 (-2578C > A), rs3025039 (+936C > T) and rs2010963 $\mathrm{G}>\mathrm{C}$ were extensively studied their associations with CHD; however, the results remained inconsistent. Recently, a systematic review and metaanalysis showed that VEGFA rs699947 polymorphism was not associated with CHD [14]. However, in this pooled analysis [14], only three case-control studies focusing on Caucasians were included, the power of this pooledanalyses might be insufficient. Of late, more epidemiologic studies with relatively large sample size focusing on the potential association of VEGFA rs699947 C > A,rs3025039 C > T and rs2010963 G > C polymorphisms with CHD risk were carried out. Considering the potential role of VEGFA rs699947 C > A, rs3025039 C > T and rs2010963 G > C polymorphism for CHD susceptibility, this coverage might increase the statistical power to assess the association of VEGFA rs699947 C > A, rs3025039 C $>\mathrm{T}$ and rs2010963 $\mathrm{G}>\mathrm{C}$ polymorphisms with CHD risk.

\section{RESULTS}

\section{Characteristics}

There were two independent groups in a paper conducted by Kangas-Kontio et al., we treated them separately [19]. According to the major inclusion and exclusion criteria, ten eligible publications with 22 independent case-control studies [19-28] were included to extract the data. The flow chart of the detailed publication selection is summarized in Figure 1. For VEGFA rs699947 C > A polymorphism, a total of 1,290 CHD cases and 1,456 non-CHD controls from seven independent casecontrol studies [19-24] were included in this metaanalysis. The year of publication ranged from 2008 to 2013. Two of these studies were conducted in Asians [20, 21] and five studies in Caucasians [19, 22-24]. Using a Goodness-of-fit chi-square calculator, the HWE test was performed; the genotype distributions of controls were all in HWE $(P>0.05)$. In total, for VEGFA rs3025039 C > $\mathrm{T}$ polymorphism, 1,344 CHD cases and 1,563 non-CHD controls from seven independent case-control studies were included [19-21, 24-26]. The year of publication ranged from 2008 to 2015 . Three of these studies were conducted in Asians [20, 21, 26] and four studies in Caucasians $[19,24,25]$. The HWE test was conducted; the genotype distributions of controls were all in $\operatorname{HWE}(P>0.05)$. And for VEGFA rs2010963 $\mathrm{G}>\mathrm{C}$ polymorphism, 1,344 CHD 
Table 2: Distribution of $V E G F A$ rs699947 C $>$ A polymorphism genotypes and alleles

\begin{tabular}{|l|l|l|l|l|l|l|l|l|l|l|l|l|l|l|}
\hline \multirow{2}{*}{ study } & \multirow{2}{*}{ year } & \multicolumn{3}{c|}{ Case genotype } & \multicolumn{2}{c|}{ Control genotype } & \multicolumn{2}{c|}{ Case allele } & \multicolumn{2}{c|}{ Control allele } & \multirow{2}{*}{ HWE } \\
\cline { 3 - 16 } & & CC & CA & AA & CC & CA & AA & C & A & C & A & \\
\hline Gu et al. & 2013 & 219 & 178 & 30 & 267 & 174 & 31 & 616 & 238 & 708 & 236 & YES \\
\hline Cui et al. & 2013 & 137 & 78 & 27 & 172 & 69 & 12 & 352 & 132 & 413 & 93 & YES \\
\hline Amoli et al. & 2012 & 9 & 27 & 14 & 15 & 26 & 9 & 45 & 55 & 56 & 44 & YES \\
\hline Guerzoni et al. & 2009 & 34 & 83 & 28 & 29 & 46 & 24 & 151 & 139 & 104 & 94 & YES \\
\hline $\begin{array}{l}\text { Kangas-Kontio } \\
\text { et al. }\end{array}$ & 2009 & 36 & 104 & 75 & 40 & 101 & 70 & 176 & 254 & 181 & 241 & YES \\
\hline $\begin{array}{l}\text { Kangas-Kontio } \\
\text { et al. }\end{array}$ & 2009 & 4 & 18 & 14 & 53 & 129 & 81 & 26 & 46 & 235 & 291 & YES \\
\hline Biselli et al. & 2008 & 47 & 96 & 32 & 30 & 51 & 27 & 190 & 160 & 111 & 105 & YES \\
\hline
\end{tabular}

Abbreviation: HWE, Hardy-Weinberg equilibrium

Table 3: Distribution of $V E G F A$ rs3025039 $\mathrm{C}>\mathrm{T}$ polymorphism genotypes and alleles

\begin{tabular}{|l|l|l|l|l|l|l|l|l|l|l|l|l|}
\hline \multirow{2}{*}{ study } & \multirow{2}{*}{ year } & \multicolumn{3}{c|}{ Case genotype } & \multicolumn{3}{c|}{ Control genotype } & \multicolumn{2}{c|}{ Case allele } & \multicolumn{2}{c|}{$\begin{array}{c}\text { Control } \\
\text { allele }\end{array}$} & \multirow{2}{*}{ HWE } \\
\cline { 3 - 14 } & & CC & CT & TT & CC & CT & TT & C & T & C & T & \\
\hline Han et al. & 2015 & 84 & 55 & 5 & 115 & 31 & 4 & 223 & 65 & 261 & 39 & YES \\
\hline Gu et al. & 2013 & 272 & 142 & 16 & 300 & 159 & 14 & 686 & 174 & 759 & 187 & YES \\
\hline Cui et al. & 2013 & 133 & 95 & 14 & 159 & 86 & 8 & 361 & 123 & 404 & 102 & YES \\
\hline Douvaras et al. & 2009 & 68 & 30 & 4 & 69 & 27 & 2 & 166 & 38 & 165 & 31 & YES \\
\hline Kangas-Kontio et al. & 2009 & 160 & 50 & 5 & 155 & 56 & 7 & 370 & 60 & 366 & 70 & YES \\
\hline Kangas-Kontio et al. & 2009 & 23 & 13 & 0 & 184 & 72 & 7 & 59 & 13 & 440 & 86 & YES \\
\hline Biselli et al. & 2008 & 133 & 36 & 6 & 83 & 23 & 2 & 302 & 48 & 189 & 27 & YES \\
\hline
\end{tabular}

Abbreviation: HWE, Hardy-Weinberg equilibrium

Table 4: Distribution of $V E G F A$ rs2010963 G>C polymorphism genotypes and allelles

\begin{tabular}{|c|c|c|c|c|c|c|c|c|c|c|c|c|}
\hline & \multirow[b]{2}{*}{ year } & \multicolumn{3}{|c|}{ Case genotype } & \multicolumn{3}{|c|}{ Control genotype } & \multicolumn{2}{|c|}{ Case allele } & \multicolumn{2}{|c|}{ Control allele } & \multirow[b]{2}{*}{ HWE } \\
\hline & & \begin{tabular}{|l|} 
case \\
GG \\
\end{tabular} & \begin{tabular}{|l} 
case \\
GC \\
\end{tabular} & \begin{tabular}{|l|} 
case \\
CC \\
\end{tabular} & \begin{tabular}{|l|} 
control \\
GG
\end{tabular} & \begin{tabular}{|l|} 
control \\
GC \\
\end{tabular} & \begin{tabular}{|l|} 
control \\
CC
\end{tabular} & Case G & \begin{tabular}{|l|} 
Case \\
C
\end{tabular} & \begin{tabular}{|l|} 
Control \\
$\mathbf{G}$ \\
\end{tabular} & Control C & \\
\hline Han et al. & 2015 & 69 & 49 & 26 & 86 & 54 & 10 & 187 & 101 & 226 & 74 & YES \\
\hline Moradzadegan et al. & 2015 & 43 & 65 & 33 & 85 & 197 & 87 & 151 & 131 & 367 & 371 & YES \\
\hline Gu et al. & 2013 & 144 & 215 & 60 & 154 & 225 & 89 & 503 & 335 & 533 & 403 & YES \\
\hline Cui et al. & 2013 & 75 & 102 & 65 & 104 & 114 & 35 & 252 & 232 & 322 & 184 & YES \\
\hline Douvaras et al. & 2009 & 37 & 49 & 16 & 29 & 55 & 14 & 123 & 81 & 113 & 83 & YES \\
\hline Kangas-Kontio et al. & 2009 & 132 & 72 & 10 & 143 & 67 & 8 & 336 & 92 & 353 & 83 & YES \\
\hline Kangas-Kontio et al. & 2009 & 22 & 10 & 3 & 154 & 90 & 19 & 54 & 16 & 398 & 128 & YES \\
\hline Petrovic et al. & 2006 & 42 & 76 & 25 & 103 & 104 & 21 & 160 & 126 & 310 & 146 & YES \\
\hline
\end{tabular}

Abbreviation: HWE, Hardy-Weinberg equilibrium

cases and 2610 non-CHD controls from eight independent case-control studies were included [19-21, 25-28]. The year of publication ranged from 2006 to 2015. Three of these studies were conducted in Asians [20, 21, 26] and five studies in Caucasians [19, 25, 27, 28]. The HWE test was conducted; the genotype distributions of controls were all in HWE $(P>0.05)$. The characteristics of the included studies are shown in Table 1. The genotype distributions of the VEGFA rs699947 C > A, rs3025039 C > T and rs2010963 polymorphisms in CHD cases and controls are presented in Table 2, Table 3 and Table 4, respectively.

\section{Quantitative synthesis}

Overall, VEGFA rs699947 $\mathrm{C}>\mathrm{A}$ polymorphism was a risk factor for CHD (A vs. C: OR $=1.19 ; 95 \% \mathrm{CI}$, $1.05-1.34 ; P=0.005$; AA vs. CC: OR $=1.33 ; 95 \% \mathrm{CI}$, $1.03-1.73 ; P=0.032$ and $\mathrm{AA}+\mathrm{CA} v s . \mathrm{CC}: \mathrm{OR}=1.33$; 95\% CI, 1.12-1.58; $P=0.001$; Table 5 and Figure 2). In subgroup analyses by ethnicity, the similar association was found among Asians (AA+CA vs. $\mathrm{CC}$ : $\mathrm{OR}=1.36$; 95\% CI, $1.10-1.68 ; P=0.005$; Table 5$)$. In subgroup analyses by 
Table 5: Meta-analysis of the $V E G F A$ rs699947 C $>$ A polymorphism and CHD

\begin{tabular}{|c|c|c|c|c|c|c|c|c|c|c|c|c|c|}
\hline & \multirow{2}{*}{$\begin{array}{l}\text { No. } \\
\text { of } \\
\text { study }\end{array}$} & \multicolumn{3}{|c|}{ Allelic comparison } & \multicolumn{3}{|c|}{ Homozygote comparison } & \multicolumn{3}{|c|}{ Dominant comparison } & \multicolumn{3}{|c|}{ Recessive comparison } \\
\hline & & OR(95\%CI) & $P$ & $\begin{array}{l}\mathrm{P}(\mathrm{Q}- \\
\text { test })\end{array}$ & OR(95\%CI) & $P$ & $\begin{array}{l}\mathrm{P}(\mathrm{Q}- \\
\text { test })\end{array}$ & OR(95\%CI) & $P$ & $\begin{array}{l}\mathrm{P}(\mathrm{Q}- \\
\text { test) }\end{array}$ & OR(95\%CI) & $P$ & \begin{tabular}{|l}
$\mathrm{P}(\mathrm{Q}-$ \\
test)
\end{tabular} \\
\hline Overall & 7 & $\begin{array}{l}1.19(1.05- \\
1.34)\end{array}$ & 0.005 & 0.117 & $\begin{array}{l}1.33(1.03- \\
1.73)\end{array}$ & 0.032 & 0.131 & $\begin{array}{l}1.33(1.12- \\
1.58)\end{array}$ & 0.001 & 0.716 & $\begin{array}{l}1.14(0.83- \\
1.55)\end{array}$ & 0.422 & 0.085 \\
\hline \multicolumn{14}{|l|}{ Ethnicity } \\
\hline Asians & 2 & $\begin{array}{l}1.37(0.96- \\
1.95) \\
\end{array}$ & 0.084 & 0.053 & $\begin{array}{l}1.76(0.75- \\
4.14) \\
\end{array}$ & 0.192 & 0.055 & $\begin{array}{l}1.36(1.10- \\
1.68)\end{array}$ & 0.005 & 0.233 & $\begin{array}{l}1.59(0.69- \\
3.66) \\
\end{array}$ & 0.275 & 0.056 \\
\hline Caucasians & 5 & $\begin{array}{l}1.09(0.92- \\
1.28)\end{array}$ & 0.324 & 0.388 & $\begin{array}{l}1.17(0.84- \\
1.64) \\
\end{array}$ & 0.361 & 0.311 & $\begin{array}{l}1.28(0.97- \\
1.70)\end{array}$ & 0.080 & 0.705 & $\begin{array}{l}0.99(0.76- \\
1.28)\end{array}$ & 0.947 & 0.273 \\
\hline \multicolumn{14}{|l|}{ Type of CHD } \\
\hline MI & 2 & $\begin{array}{l}1.15(0.91- \\
1.47)\end{array}$ & 0.242 & 0.349 & $\begin{array}{l}1.36(0.83- \\
2.24)\end{array}$ & 0.220 & 0.319 & $\begin{array}{l}1.30(0.83- \\
2.03)\end{array}$ & 0.245 & 0.362 & $\begin{array}{l}1.15(0.81- \\
1.64)\end{array}$ & 0.432 & 0.503 \\
\hline Non-MI & 5 & $\begin{array}{l}1.20(0.96- \\
1.50)\end{array}$ & 0.108 & 0.055 & $\begin{array}{l}1.36(0.84- \\
2.21)\end{array}$ & 0.213 & 0.065 & $\begin{array}{l}1.34(1.11- \\
1.60)\end{array}$ & 0.002 & 0.582 & $\begin{array}{l}1.13(0.71- \\
1.82)\end{array}$ & 0.604 & 0.032 \\
\hline
\end{tabular}

Abbreviations: MI: myocardial infarction;

CHD: coronary heart disease

Table 6: Meta-analysis of the $V E G F A$ rs3025039 C $>$ T polymorphism and CHD

\begin{tabular}{|c|c|c|c|c|c|c|c|c|c|c|c|c|c|}
\hline & \multirow{2}{*}{$\begin{array}{l}\text { No. of } \\
\text { study }\end{array}$} & \multicolumn{3}{|c|}{ Allelic comparison } & \multicolumn{3}{|c|}{ Homozygote comparison } & \multicolumn{3}{|c|}{ Dominant comparison } & \multicolumn{3}{|c|}{ Recessive comparison } \\
\hline & & OR(95\%CI) & $P$ & $\begin{array}{l}\mathrm{P}(\mathrm{Q}- \\
\text { test) }\end{array}$ & OR(95\%CI) & $P$ & $\begin{array}{l}\mathrm{P}(\mathrm{Q}- \\
\text { test })\end{array}$ & OR(95\%CI) & $P$ & \begin{tabular}{|l}
$P(Q-$ \\
test $)$
\end{tabular} & OR(95\%CI) & $P$ & $\begin{array}{l}\mathrm{P}(\mathrm{Q}- \\
\text { test) }\end{array}$ \\
\hline Overall & 7 & $\begin{array}{l}1.16(1.01- \\
1.33)\end{array}$ & 0.035 & 0.114 & $\begin{array}{l}1.40(0.91- \\
2.15)\end{array}$ & 0.125 & 0.800 & $\begin{array}{l}1.21(0.95- \\
1.55)\end{array}$ & 0.117 & 0.065 & $\begin{array}{l}1.33(0.87- \\
2.04)\end{array}$ & 0.189 & 0.862 \\
\hline \multicolumn{14}{|l|}{ Ethnicity } \\
\hline Asians & 3 & $\begin{array}{l}1.34(0.96- \\
1.87) \\
\end{array}$ & 0.089 & 0.031 & $\begin{array}{l}1.57(0.93- \\
2.65) \\
\end{array}$ & 0.089 & 0.687 & $\begin{array}{l}1.42(0.91- \\
2.22)\end{array}$ & 0.119 & 0.012 & $\begin{array}{l}1.46(0.87- \\
2.45)\end{array}$ & 0.149 & 0.786 \\
\hline Caucasians & 4 & $\begin{array}{l}1.01(0.80- \\
1.29)\end{array}$ & 0.906 & 0.661 & $\begin{array}{l}1.09(0.51- \\
2.33)\end{array}$ & 0.825 & 0.626 & $\begin{array}{l}1.02(0.77- \\
1.33)\end{array}$ & 0.914 & 0.686 & $\begin{array}{l}1.09(0.51- \\
2.31)\end{array}$ & 0.832 & 0.635 \\
\hline \multicolumn{14}{|l|}{$\begin{array}{ll}\text { Type } \\
\text { CHD }\end{array}$} \\
\hline MI & 3 & $\begin{array}{l}0.99(0.75- \\
1.30)\end{array}$ & 0.926 & 0.490 & $\begin{array}{l}0.91(0.38- \\
2.20)\end{array}$ & 0.835 & 0.555 & $\begin{array}{l}1.01(0.74- \\
1.37)\end{array}$ & 0.974 & 0.480 & $\begin{array}{l}0.91(0.38- \\
2.17)\end{array}$ & 0.823 & 0.569 \\
\hline Non-MI & 4 & $\begin{array}{l}1.29(0.98- \\
1.68)\end{array}$ & 0.065 & 0.068 & $\begin{array}{l}1.60(0.98- \\
2.63)\end{array}$ & 0.063 & 0.852 & $\begin{array}{l}1.33(0.93- \\
1.90)\end{array}$ & 0.113 & 0.027 & $\begin{array}{l}1.50(0.92- \\
2.45)\end{array}$ & 0.106 & 0.904 \\
\hline
\end{tabular}

Abbreviations: MI: myocardial infarction;

CHD: coronary heart disease

Table 7: Meta-analysis of the $V E G F A 2010963$ G $>C$ polymorphism and CHD

\begin{tabular}{|c|c|c|c|c|c|c|c|c|c|c|c|c|c|}
\hline & \multirow{2}{*}{$\begin{array}{l}\text { No. of } \\
\text { study }\end{array}$} & \multicolumn{3}{|c|}{ Allelic comparison } & \multicolumn{3}{|c|}{ Homozygote comparison } & \multicolumn{3}{|c|}{ Dominant comparison } & \multicolumn{3}{|c|}{ Recessive comparison } \\
\hline & & OR(95\%CI) & $P$ & \begin{tabular}{|l}
$\begin{array}{l}P(Q- \\
\text { test }\end{array}$ \\
\end{tabular} & OR( $(95 \% \mathrm{CI})$ & $P$ & $\begin{array}{l}P(Q- \\
\text { test }\end{array}$ & OR( $(95 \% \mathrm{CI})$ & $P$ & $\begin{array}{l}\begin{array}{l}P(Q- \\
\text { test }\end{array} \\
\end{array}$ & OR $(95 \% \mathrm{CI})$ & $P$ & $\begin{array}{l}P(Q- \\
\text { test }\end{array}$ \\
\hline Overall & 8 & $1.17(0.93,1.47)$ & 0.182 & $<0.001$ & $1.43(0.87,2.35)$ & 0.160 & $<0.001$ & $1.12(0.87,1.45)$ & 0.379 & 0.006 & $1.41(0.93,2.14)$ & 0.102 & 0.001 \\
\hline \multicolumn{14}{|l|}{ Ethnicity } \\
\hline Asians & 3 & $1.31(0.83,2.06)$ & 0.242 & $<0.001$ & $1.76(0.65,4.78)$ & 0.269 & $<0.001$ & $1.25(0.88,1.78)$ & 0.210 & 0.061 & $1.65(0.64,4.25)$ & 0.297 & $<0.001$ \\
\hline Caucasians & 5 & $1.09(0.82,1.43)$ & 0.562 & 0.019 & $1.25(0.70,2.21)$ & 0.454 & 0.042 & $1.02(0.68,1.54)$ & 0.922 & 0.008 & $1.25(0.92,1.69)$ & 0.146 & 0.450 \\
\hline \multicolumn{14}{|l|}{ Type of CHD } \\
\hline MI & 4 & $1.17(0.87,1.59)$ & 0.306 & 0.062 & $1.62(1.05,2.50)$ & 0.029 & 0.163 & $1.15(0.74,1.78)$ & 0.527 & 0.038 & $1.51(1.01,2.27)$ & 0.047 & 0.604 \\
\hline Non-MI & 4 & $1.18,0.83,1.67$ & 0.368 & $<0.001$ & $1.41(0.66,3.00)$ & 0.376 & $<0.001$ & $1.09(0.77,1.56)$ & 0.625 & 0.013 & $1.43(0.74,2.75)$ & 0.287 & $<0.001$ \\
\hline
\end{tabular}

Abbreviations: MI: myocardial infarction;

CHD: coronary heart disease

the type of CHD, VEGFA rs699947 C > A polymorphism was also associated with risk of non-MI (AA+CA vs. CC: $\mathrm{OR}=1.34 ; 95 \% \mathrm{CI}, 1.11-1.60 ; P=0.002$; Table 5).

For $V E G F A$ rs3025039 $\mathrm{C}>\mathrm{T}$ polymorphism, this SNP was associated with increased risk of overall CHD in one genetic models ( $\mathrm{T} v s . \mathrm{C}$ : $\mathrm{OR}=1.16 ; 95 \% \mathrm{CI}, 1.01$ - 1.33; $P=0.035$; Table 6 and Figure 3$)$. However, in a subgroup analysis by ethnicity and the type of CHD, the association was not identified (Table 6).
For VEGFA rs2010963 $\mathrm{G}>\mathrm{C}$ polymorphism, this SNP was not associated with risk of overall CHD (Table 7). However, in a subgroup analysis by the type of CHD, the polymorphism was associated with MI risk (CC vs. GG: $\mathrm{OR}=1.62 ; 95 \% \mathrm{CI}, 1.05-2.50 ; P=0.029 ; \mathrm{CC} v s$. $\mathrm{CG}+\mathrm{GG}: \mathrm{OR}=1.51 ; 95 \% \mathrm{CI}, 1.01-2.27 ; P=0.047$; Table 7 and Figure 4). 
Table 8: Quality assessment of the included studies

\begin{tabular}{|c|c|c|c|c|c|c|c|c|c|c|}
\hline \multirow[b]{2}{*}{ Study } & \multirow[b]{2}{*}{ Year } & \multicolumn{4}{|l|}{ Selection } & \multirow[b]{2}{*}{$\begin{array}{l}\text { Comparability } \\
\text { of the cases and } \\
\text { controls }\end{array}$} & \multicolumn{3}{|l|}{ Exposure } & \multirow[b]{2}{*}{$\begin{array}{l}\text { Total } \\
\text { stars }\end{array}$} \\
\hline & & $\begin{array}{l}\text { Adequate } \\
\text { case } \\
\text { definition }\end{array}$ & $\begin{array}{l}\text { Representativeness } \\
\text { of the cases }\end{array}$ & $\begin{array}{l}\text { Selection } \\
\text { of the } \\
\text { controls }\end{array}$ & $\begin{array}{l}\text { Definition of } \\
\text { Controls }\end{array}$ & & $\begin{array}{l}\text { Ascertainment of } \\
\text { exposure }\end{array}$ & \begin{tabular}{|l|} 
Same \\
ascertainment \\
method for \\
cases and \\
controls
\end{tabular} & $\begin{array}{l}\text { Non- } \\
\text { Response } \\
\text { rate }\end{array}$ & \\
\hline Han et al. & 2015 & $*$ & $*$ & - & $*$ & $* *$ & $* *$ & $*$ & - & 8 \\
\hline $\begin{array}{l}\text { Moradzadegan } \\
\text { et al. }\end{array}$ & 2015 & $*$ & $*$ & - & $*$ & $* *$ & $*$ & $*$ & - & 7 \\
\hline Gu et al. & 2013 & * & $*$ & - & $*$ & $* *$ & $* *$ & * & - & 8 \\
\hline Cui et al. & 2013 & * & $*$ & - & $*$ & $* *$ & $*$ & * & - & 7 \\
\hline Amoli et al. & 2012 & $*$ & $*$ & - & $*$ & $* *$ & $* *$ & $*$ & - & 8 \\
\hline Guerzoni et al. & 2009 & $*$ & $*$ & - & $*$ & $* *$ & $* *$ & $*$ & - & 8 \\
\hline Douvaras et al. & 2009 & $*$ & $*$ & - & $*$ & $* *$ & $* *$ & - & - & 7 \\
\hline $\begin{array}{l}\text { Kangas-Kontio } \\
\text { et al. }\end{array}$ & 2009 & * & $*$ & $*$ & * & $* *$ & $* *$ & * & - & 9 \\
\hline $\begin{array}{l}\text { Kangas-Kontio } \\
\text { et al. }\end{array}$ & 2009 & * & $*$ & $*$ & $*$ & $* *$ & $* *$ & * & - & 9 \\
\hline Biselli et al. & 2008 & $*$ & - & - & $*$ & $* *$ & $* *$ & $*$ & - & 7 \\
\hline Petrovic et al. & 2006 & $*$ & $*$ & - & $*$ & $* *$ & $* *$ & $*$ & - & 8 \\
\hline
\end{tabular}

\section{Tests for publication bias}

The shape of Begg's funnel plot test was symmetrical for VEGFA rs699947 C > A, rs3025039 C $>\mathrm{T}$ and rs2010963 $\mathrm{G}>\mathrm{C}$ polymorphisms (rs699947 C > A polymorphism: A $v s$. C: Begg's test $P=0.764$; AA $v s$.
CC: Begg's test $P=0.368$; AA $+\mathrm{CA}$ vs. CC: Begg's test $P=0.548$ and AA vs. CC $+\mathrm{CA}$ : Begg's test $P=0.230$; rs3025039 C $>$ T polymorphism: T vs. C: Begg's test $P=$ 0.764; TT vs. CC: Begg's test $P=1.000$; TT $+\mathrm{CT}$ vs. CC: Begg's test $P=0.548$ and TT vs. CT $+\mathrm{CC}$ : Begg's test $P=$ 1.000; rs2010963 G > C polymorphism: C vs. G: Begg's

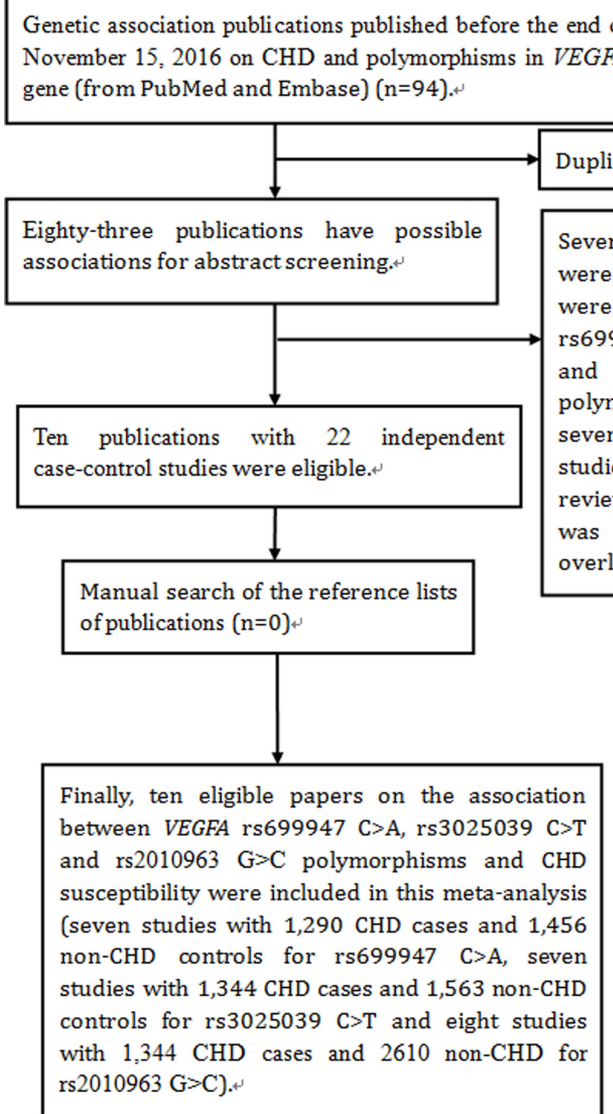

Figure 1: Flow diagram of studies selection. 
test $P=1.000 ; \mathrm{CC}$ vs. GG: Begg's test $P=1.000 ; \mathrm{CC}+\mathrm{GC}$ vs. GG: Begg's test $P=1.000$ and $\mathrm{CC}$ vs. GG+GC: Begg's test $P=0.902$; Figure 5 , Figure 6 and Figure 7). The statistical results of Egger's test still demonstrated there were no evidence of bias for these two SNPs (rs699947 C > A polymorphism: A vs. C: Egger's test $P=0.627$; AA vs. CC: Egger's test $P=0.257$; AA+CA vs. CC: Egger's test $P=0.394$ and AA vs. CC+CA: Egger's test $P=0.356$; rs3025039 C $>$ T polymorphism: T vs. C: Egger's test $P$ $=0.598$; TT vs. CC: Egger's test $P=0.783 ; \mathrm{TT}+\mathrm{CT} v s$. CC: Egger's test $P=0.475$ and TT vs. CT $+\mathrm{CC}$ : Egger's test $P=0.660 ;$ rs2010963 $\mathrm{G}>\mathrm{C}$ polymorphism: $\mathrm{C} v s$. G: Egger's test $P=0.608$; CC vs. GG: Egger's test $P=$ 0.445; CC+GC vs. GG: Egger's test $P=0.899$ and $\mathrm{CC}$ vs. GC+GG: Egger's test $P=0.318$ ).

\section{Tests for sensitivity analyses}

An independent study involved in the present pooled-analysis was omitted each time to assess the influence of the data-set on the pooled ORs, and the exclusion of anyone did not materially alter the corresponding pooled ORs (Figure 8, Figure 9 and Figure 10, data not shown).

\section{Tests for heterogeneity}

In some genetic models, we found significant heterogeneity across studies in the present meta-analysis

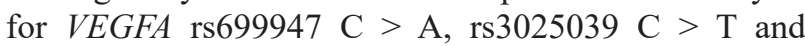
rs2010963 $\mathrm{G}>\mathrm{C}$ polymorphisms. Type of CHD and ethnicity were defined as characteristics for evaluation of potential heterogeneity. Results of subgroup analyses demonstrated that studies conducted in Asians and nonMI subgroups may contribute to the major source of heterogeneity for VEGFA rs699947 C > A, rs3025039 C > $\mathrm{T}$ and rs2010963 $\mathrm{G}>\mathrm{C}$ polymorphisms.

\section{Results of quality assessment}

We used Newcastle-Ottawa Quality Assessment Scale to assess the quality score of the eligible studies. When scores $\geq 7$ stars, the study was considered as high-

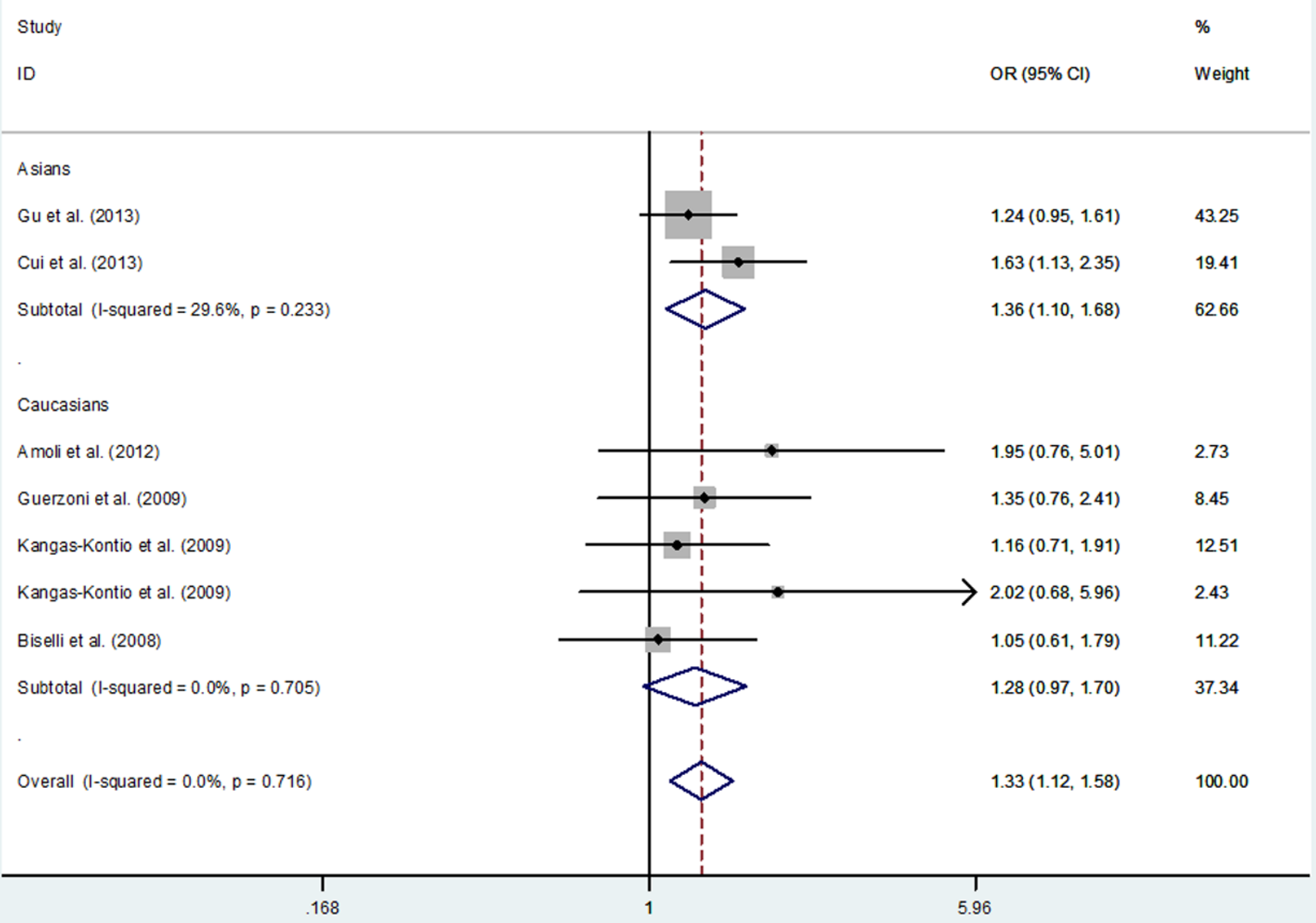

Figure 2: Meta-analysis for the association between $V E G F A$ rs699947 C $>$ A polymorphism and CHD risk (AA+CA vs. CC genetic model, fixed-effects model). 
quality. The results indicated that all included studies were high-quality, suggesting the reliability of our findings (Table 8).

\section{DISCUSSION}

Besides environmental risk factors (e.g. smoking, drinking, and sedentary lifestyle et al.), multiple evidences support a vital role of genetics in determining susceptibility for CHD. The involvement of VEGFA in inflammation and neovascularization may underlie the major mechanism responsible for the association between VEGFA genotypes and risk of CHD. Recently, several investigations on the molecular epidemiology considering on the correlation of VEGFA polymorphism with CHD risk were performed; however, the findings remained conflicting. With respect to VEGFA polymorphisms, a recent systemic review and meta-analysis with small sample sizes on this issue did not suggest any association between VEGFA rs699947 C > A polymorphism and risk of CHD [14]. After that, some case-control studies reported that rs699947 $\mathrm{C}>\mathrm{A}$ polymorphism in VEGFA gene have been implicated in CHD risk, especially in Asians. Thus, we conducted a meta-analysis involving a total of 2097 CHD cases and 2867 controls subjects from ten publications including 22 trails to assess the potential associations between two commonly functional SNPs (rs699947 C > A, rs3025039 C > T and rs2010963 G > C) in VEGFA gene and CHD risk.

For VEGFA rs699947 C > A polymorphism, seven independent studies focusing on the relationship of this SNP with CHD risk were included. A recent case-control study has reported positive signals of VEGFA rs699947 C $>$ A polymorphism with risk of CHD [21]; contrastingly, others showed the variants of VEGFA rs699947 C > A polymorphism did not influence risk of CHD [19, 20, 22-24]. As shown in Table 4, VEGFA rs699947 C $>$ A polymorphism was identified to be associated with the development of CHD. The A allele carriers indicated higher CHD susceptibility in comparison with the $\mathrm{C}$ allele carriers. In subgroup analyses by ethnicity, the similar association was found among Asians, but not Caucasians. Our results were consistent with the findings

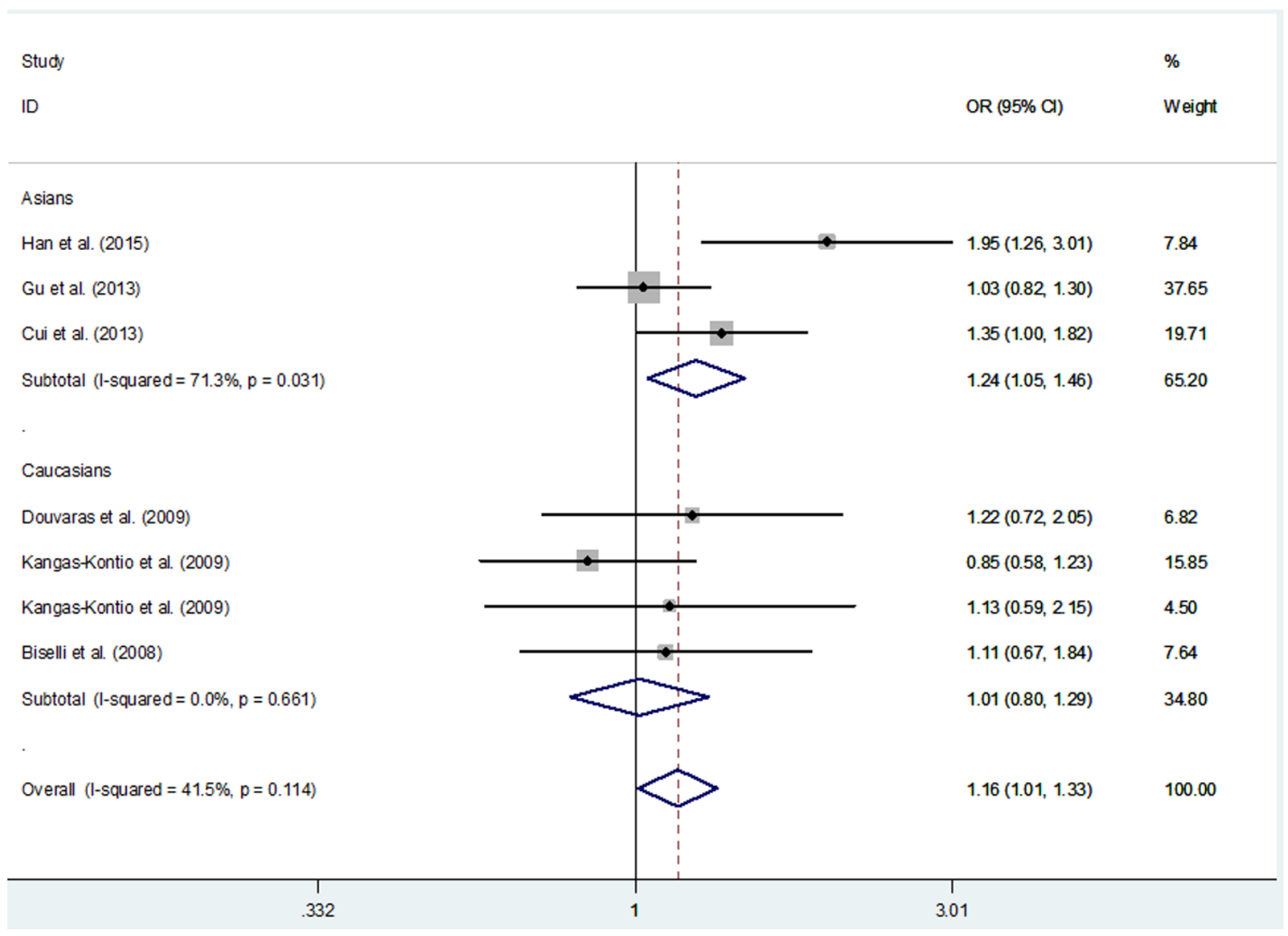

Figure 3: Meta-analysis for the association between VEGFA rs3025039 C > T polymorphism and CHD risk (T vs. C genetic model; fixed-effects model). 
of a previous meta-analysis [14]. A previous study indicated the expression levels of VEGF mRNA in CHD patients carrying the VEGF rs699947 AA genotype were significantly lower than those who carried the VEGF rs699947 AC or CC genotypes [29]. This study also suggested that CHD patients carrying the VEGF rs699947 A allele might have more chances in developing better coronary collaterals [29]. Gokkusu et al. reported that VEGF might be a cardio-protective factor [30]. In this study, we found that VEGFA rs699947 C > A polymorphism was correlated with increased risk of CHD, suggesting the presence of the A allele, which was associated with lower expression of VEGF mRNA and activity, might lead to the increased risk of CHD.

Rs3025039 $\mathrm{C}>\mathrm{T}$ polymorphism locates on the 3'-UTR region of VEGFA gene. Thus, it may regulate post-transcription and then influence gene expression. VEGFA rs3025039 C > T polymorphism was well known to influence the secreted levels of VEGFA protein and has been identified to have overt association in most studies [31]. This SNP exhibited a very strong association with epithelial ovarian cancer status and poorer prognosis [31].
A prior study indicated this 3'-UTR polymorphism was associated with the occurrence and severity of diabetic nephropathy [32]. Recently, several case-control studies focused on the association between VEGFA rs3025039 C $>\mathrm{T}$ polymorphism and CHD risk. Han et al. reported that VEGFA rs3025039 CT genotype and C allele appeared to be a genetic risk factor for CHD [26]. Cui et al. also found $V E G F A$ rs3025039 C > T polymorphism conferred a borderline increased risk to CHD [21]. As demonstrated in Table 5, the combined evidence suggested that VEGFA rs3025039 $\mathrm{C}>\mathrm{T}$ polymorphism was a risk factor for overall CHD. In a subgroup analysis by ethnicity and the type of CHD, a borderline increased risk to $\mathrm{CHD}$ was also found in Asians and non-MI subgroups $(P=0.089$ and $P$ $=0.065$, respectively). These findings demonstrated the presence of the $\mathrm{T}$ allele may alter mRNA and secreted levels of VEGFA protein and then led to the increased risk of CHD.

Rs2010963 $\mathrm{G}>\mathrm{C}$ polymorphism is located in the 5 '-untranslated region in VEGFA gene. According to previous reports, rs2010963 $\mathrm{G}>\mathrm{C}$ polymorphism was a genetic marker of microvascular complications in cases

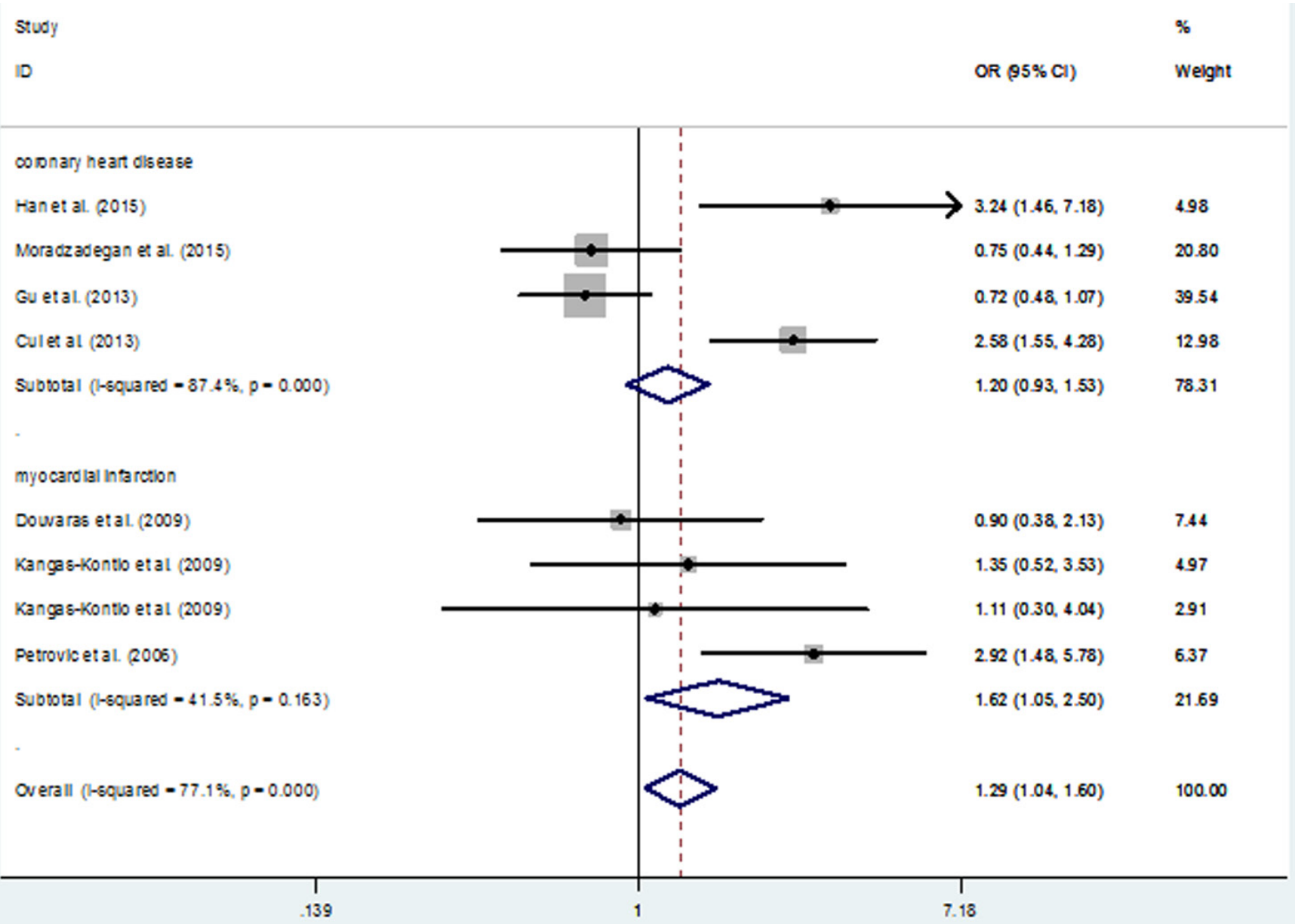

Figure 4: Meta-analysis for the association between VEGFA 2010963 G > C polymorphism and CHD risk (CC vs. GG genetic model; fixed-effects model). 


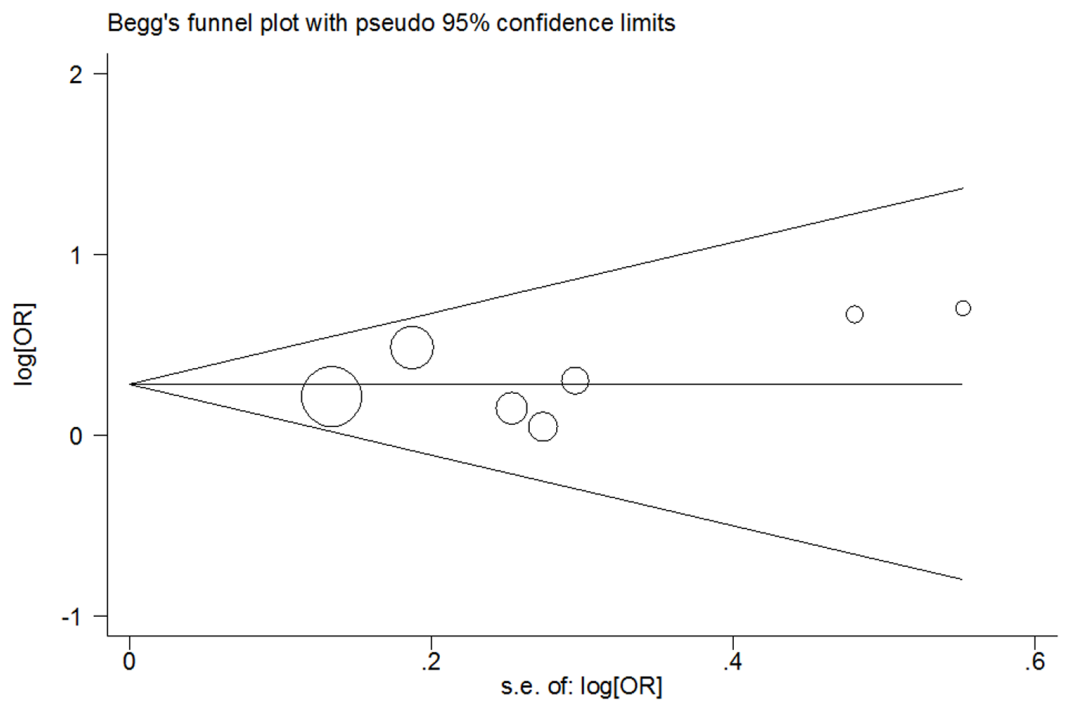

Figure 5: Begg's funnel plot of meta-analysis for the association between VEGFA rs699947 C $>$ A polymorphism and CHD risk (AA+CA vs. CC genetic model).

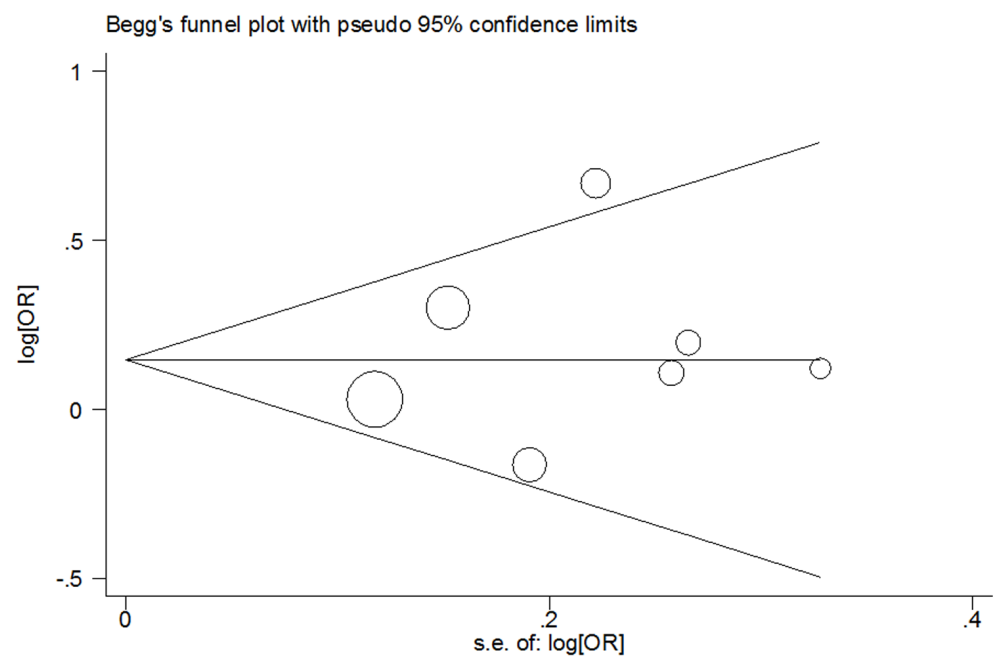

Figure 6: Begg's funnel plot of meta-analysis for the association between VEGFA rs3025039 C $>$ T polymorphism and CHD risk ( $T$ vs. $C$ genetic model).

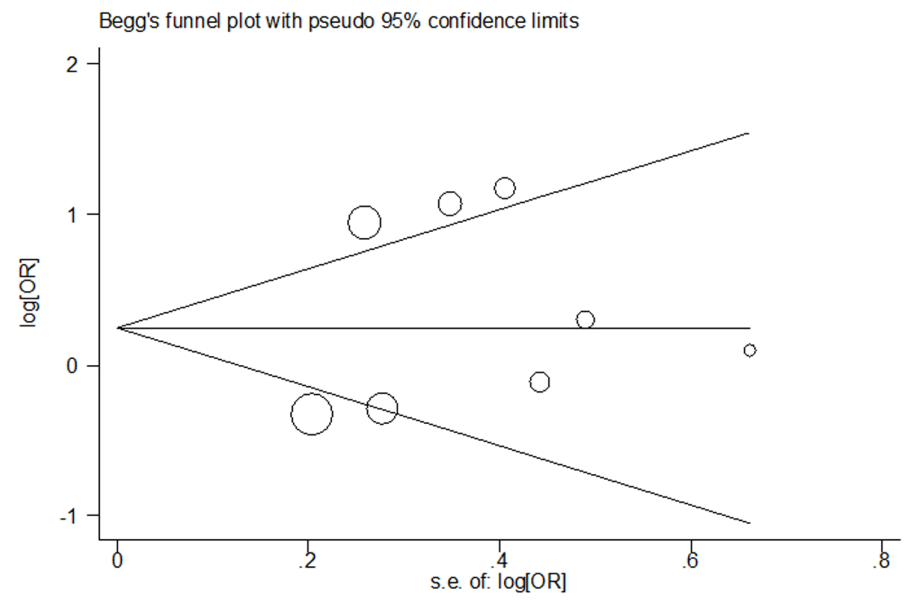

Figure 7: Begg's funnel plot of meta-analysis for the association between $V E G F A$ rs2010963 G $>C$ polymorphism and CHD risk (CC vs. GG genetic model) 
with type 2 diabetes [33-35]. Compared to those with VEGFA GG and GC genotypes, a remarkably higher VEGF serum level was found in healthy individuals with the VEGFA rs2010963 CC genotype [33, 36]. The CC genotype of the rs $2010963 \mathrm{G}>\mathrm{C}$ polymorphism has been demonstrated to be related to heart failure induced

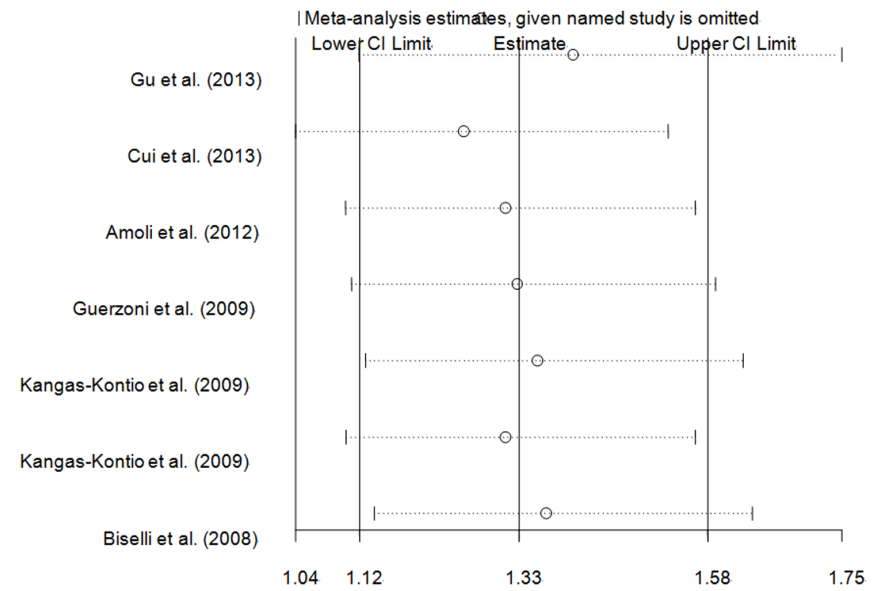

Figure 8: Sensitivity analysis of the overall CHD meta-analysis for VEGFA rs699947 C > A polymorphism.

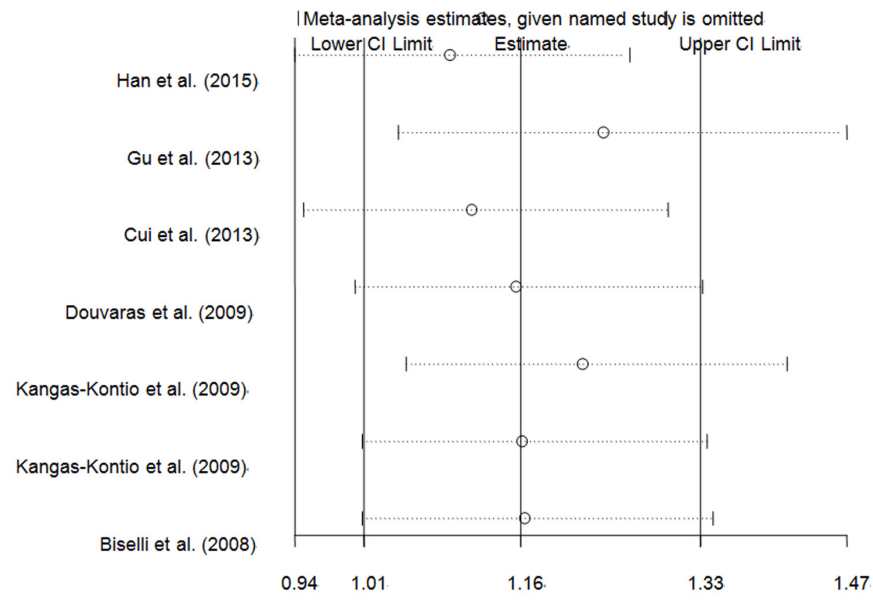

Figure 9: Sensitivity analysis of the overall CHD meta-analysis for $V E G F A$ rs3025039 C $>$ T polymorphism.

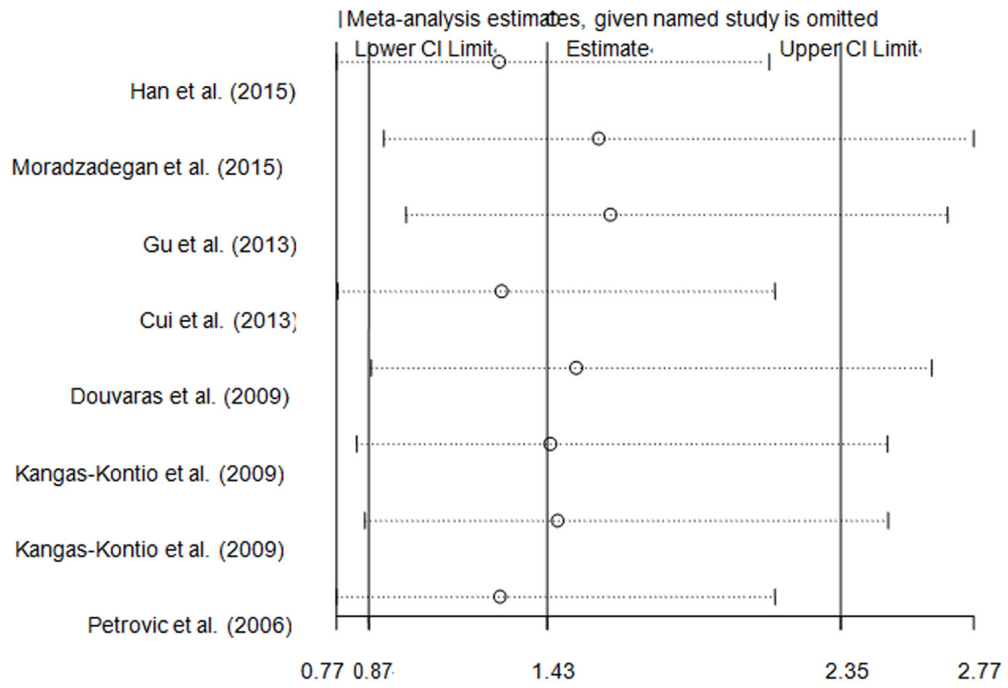

Figure 10: Sensitivity analysis of the overall CHD meta-analysis for VEGFA rs2010963 G > C polymorphism. 
by acute myocardial infarction [25]. Several studies have investigated the association between VEGFA rs2010963 $\mathrm{G}>\mathrm{C}$ polymorphism and CHD risk. After meta-analyses in our study, we concluded that the CC genotype of the polymorphism may increase risk of MI.

Similar to other meta-analyses, some potential limitations of our meta-analysis should be acknowledged. First, although bias tests showed there was no significant publication bias in our meta-analysis and a comprehensive literature search was well designed, it is likely that certain unpublished studies might be overlooked. Second, the association of VEGFA rs699947 C > A, rs3025039 C > T and rs2010963 $\mathrm{G}>\mathrm{C}$ polymorphisms with risk of $\mathrm{CHD}$ was assessed based on unadjusted estimates. If the detailed data of individuals were available, a more precise metaanalysis could be carried out. Third, for lack of individuallevel data, we did not conduct a further analysis to assess any potential interactions between gene-gene and genemetabolic traits. Finally, significant heterogeneity between the eligible studies for VEGFA rs699947 C > A, rs3025039 $\mathrm{C}>\mathrm{T}$ and rs2010963 $\mathrm{G}>\mathrm{C}$ polymorphisms was found. Our results should be interpreted with very cautions.

In conclusion, our findings indicate that VEGFA rs699947 C > A, rs3025039 $\mathrm{C}>\mathrm{T}$ and rs2010963 $\mathrm{G}>\mathrm{C}$ polymorphisms may be risk factors for the development of CHD. As the participants in some subgroup are currently limited, further well-designed studies with larger sample size to investigate the role of these loci are needed. Moreover, interactions of gene-gene and geneenvironment should not be ignored.

\section{MATERIALS AND METHODS}

\section{Search strategy}

Genetic association publications published before the end of November 15, 2016 on CHD and polymorphisms in VEGFA gene were retrieved through a search of PubMed and EMBASE online databases with keywords: (vascular endothelial growth factor-A or VEGFA) and and (polymorphism or variant or SNP) and (coronary artery disease or CAD or coronary heart disease or CHD or myocardial infarction or MI). All bibliographies cited in eligible publications, reviews and meta-analysis were examined to retrieve the potential publications.

\section{Inclusion and exclusion criteria}

The major criteria of eligible studies were: (a) studies focused on the relationship of VEGFA rs699947 $\mathrm{C}>\mathrm{A}, \mathrm{rs} 3025039 \mathrm{C}>\mathrm{T}$ and rs2010963 $\mathrm{G}>$ C polymorphisms with CHD risk; (b) sufficient data were presented to determine the odds ratios (ORs) with their 95\% confidence intervals (CIs) and $P$ value, and (c) the genotyping method, equipment, and protocols used or provided reference were described in publication. Accordingly, publications providing insufficient data, CHD treatment, not case-control design, overlapping data, reviews and meta-analysis were excluded.

\section{Data extraction}

Two authors (Y. Wang and Q. Huang) reviewed and collected information independently from eligible studies in accordance with the major criteria for inclusion and exclusion mentioned above. The following data: the surname of first author, year of publication, country, ethnicity of the participants, type of CHD [myocardial infarction (MI) or non-MI], genotyping method as well as allele and genotype frequencies, were entered into a database. In case of conflicting evaluations, disagreements over study/data inclusion were resolved by a discussion among all reviewers.

\section{Quality assessment}

The Newcastle-Ottawa Quality Assessment Scale was harnessed to assess the quality score of the eligible studies. And scores $\geq 7$ stars were considered as highquality study [15].

\section{Statistical analysis}

A Goodness-of-fit chi-square calculator (http:// ihg.gsf.de/cgi-bin/hw/hwa1.pl) was used to examine the deviation from HWE in controls. The strength of correlation between SNPs in VEGFA gene and CHD risk was assessed by ORs with the corresponding 95\% CIs. Type of CHD (MI or non-MI) and ethnicity were considered as characteristics for evaluation of potential heterogeneity. Ethnicity group was defined as Asians and Caucasians. We used Chi-square based $I^{2}$-statistic test and Q statistical test to analyze the potential heterogeneity among the studies. $P<0.10$ or $I^{2}>50 \%$ indicates high heterogeneity, random-effects model (the DerSimonian and Laird method) was used to calculate the pooled ORs and CIs [16]; otherwise, the fixed-effects model (the Mantel-Haenszel method) was used [17]. Funnel plots and Egger's regression test were harnessed to diagnose the potential publication bias [18], and a $P<0.1$ was defined as statistical significance. Sensitivity analysis, which assessed the influence of each independent study on the pooled ORs with their corresponding 95\% CIs, was also carried out to evaluate the stability of our results. All $P$ values were defined as two-sided at the $P=0.05$ level. All data analysis was performed with Stata 12.0 software for windows (Stata Corporation, College Station, TX). 


\section{CONFLICTS OF INTEREST}

There is no conflict of interest.

\section{GRANT SUPPORT}

This study was supported by Fujian Province health department fund for innovation in medicine (2007-CX16).

\section{REFERENCES}

1. Lloyd-Jones D, Adams R, Carnethon M, De Simone G, Ferguson TB, Flegal K, Ford E, Furie K, Go A, Greenlund K, Haase N, Hailpern S, Ho M, et al. Heart disease and stroke statistics - 2009 update: a report from the American Heart Association Statistics Committee and Stroke Statistics Subcommittee. Circulation. 2009; 119: 480-6. doi: 10.1161/ CIRCULATIONAHA.108.191259.

2. Okrainec K, Banerjee DK, Eisenberg MJ. Coronary artery disease in the developing world. Am Heart J. 2004; 148: 7-15. doi: 10.1016/j.ahj.2003.11.027.

3. Song C, Chang Z, Magnusson PK, Ingelsson E, Pedersen NL. Genetic factors may play a prominent role in the development of coronary heart disease dependent on important environmental factors. J Intern Med. 2014; 275: 631-9. doi: 10.1111/joim.12177.

4. Ferrara N. Vascular endothelial growth factor: basic science and clinical progress. Endocr Rev. 2004; 25: 581-611. doi: 10.1210/er.2003-0027.

5. Ferrara N, Davis-Smyth T. The biology of vascular endothelial growth factor. Endocr Rev. 1997; 18: 4-25. doi: 10.1210/edrv.18.1.0287.

6. Carmeliet P, Jain RK. Angiogenesis in cancer and other diseases. Nature. 2000; 407: 249-57. doi: $10.1038 / 35025220$.

7. Moulton KS, Vakili K, Zurakowski D, Soliman M, Butterfield C, Sylvin E, Lo KM, Gillies S, Javaherian K, Folkman J. Inhibition of plaque neovascularization reduces macrophage accumulation and progression of advanced atherosclerosis. Proc Natl Acad Sci U S A. 2003; 100: 4736-41. doi: 10.1073/pnas.0730843100.

8. Lee KW, Lip GY, Blann AD. Plasma angiopoietin-1, angiopoietin-2, angiopoietin receptor tie-2, and vascular endothelial growth factor levels in acute coronary syndromes. Circulation. 2004; 110: 2355-60. doi: 10.1161/01.CIR.0000138112.90641.7F.

9. Kucukardali Y, Aydogdu S, Ozmen N, Yonem A, Solmazgul E, Ozyurt M, Cingozbay Y, Aydogdu A. The relationship between severity of coronary artery disease and plasma level of vascular endothelial growth factor. Cardiovasc Revasc Med. 2008; 9: 66-70. doi: 10.1016/j. carrev.2007.11.005.

10. Vincenti V, Cassano C, Rocchi M, Persico G. Assignment of the vascular endothelial growth factor gene to human chromosome 6p21.3. Circulation. 1996; 93: 1493-5.

11. Stevens A, Soden J, Brenchley PE, Ralph S, Ray DW. Haplotype analysis of the polymorphic human vascular endothelial growth factor gene promoter. Cancer Res. 2003; 63: 812-6.

12. Shahbazi M, Fryer AA, Pravica V, Brogan IJ, Ramsay HM, Hutchinson IV, Harden PN. Vascular endothelial growth factor gene polymorphisms are associated with acute renal allograft rejection. J Am Soc Nephrol. 2002; 13: 260-4.

13. Marsh S, Nakhoul FM, Skorecki K, Rubin A, Miller BP, Leibu R, Levy NS, Levy AP. Hypoxic induction of vascular endothelial growth factor is markedly decreased in diabetic individuals who do not develop retinopathy. Diabetes Care. 2000; 23: 1375-80.

14. Chen HL, Liu K. Vascular endothelial growth factor polymorphisms and coronary artery disease: a systemic review and meta-analysis. Int J Cardiol. 2014; 172: e220-4. doi: 10.1016/j.ijcard.2013.12.156.

15. Wang W, Shao Y, Tang S, Cheng X, Lian H, Qin C. Peroxisome proliferator-activated receptor-gamma (PPARgamma) Pro12Ala polymorphism and colorectal cancer (CRC) risk. Int J Clin Exp Med. 2015; 8: 4066-72.

16. DerSimonian R, Laird N. Meta-analysis in clinical trials. Control Clin Trials. 1986; 7: 177-88.

17. Mantel N, Haenszel W. Statistical aspects of the analysis of data from retrospective studies of disease. J Natl Cancer Inst. 1959; 22: 719-48.

18. Egger M, Davey Smith G, Schneider M, Minder C. Bias in meta-analysis detected by a simple, graphical test. BMJ. 1997; 315: 629-34.

19. Kangas-Kontio T, Tapanainen JM, Huikuri H, Savolainen ER, Paivansalo M, Kauma H, Kesaniemi YA, Savolainen MJ, Kakko S. Variation in the vascular endothelial growth factor gene, carotid intima-media thickness and the risk of acute myocardial infarction. Scand J Clin Lab Invest. 2009; 69: 335-43. doi: 10.1080/00365510802607520.

20. Gu H, Chen W, Yin J, Chen S, Zhang J, Gong J. Methionine sulfoxide reductase A rs10903323 G/A polymorphism is associated with increased risk of coronary artery disease in a Chinese population. Clin Biochem. 2013; 46: 1668-72. doi: 10.1016/j.clinbiochem.2013.07.011.

21. Cui QT, Li Y, Duan CH, Zhang W, Guo XL. Further evidence for the contribution of the vascular endothelial growth factor gene in coronary artery disease susceptibility. Gene. 2013; 521: 217-21. doi: 10.1016/j.gene.2013.03.091.

22. Amoli MM, Amiri P, Alborzi A, Larijani B, Saba S, Tavakkoly-Bazzaz J. VEGF gene mRNA expression in patients with coronary artery disease. Mol Biol Rep. 2012; 39: 8595-9. doi: 10.1007/s11033-012-1713-x.

23. Guerzoni AR, Biselli PM, Godoy MF, Souza DR, Haddad R, Eberlin MN, Pavarino-Bertelli EC, GoloniBertollo EM. Homocysteine and MTHFR and VEGF gene polymorphisms: impact on coronary artery disease. Arq 
Bras Cardiol. 2009; 92: 263-8.

24. Biselli PM, Guerzoni AR, de Godoy MF, Pavarino-Bertelli EC, Goloni-Bertollo EM. Vascular endothelial growth factor genetic variability and coronary artery disease in Brazilian population. Heart Vessels. 2008; 23: 371-5. doi: 10.1007/s00380-008-1057-6.

25. Douvaras $\mathrm{P}$, Antonatos DG, Kekou K, Patsilinakos S, Chouliaras G, Christou A, Andrikou A, Kanavakis E. Association of VEGF gene polymorphisms with the development of heart failure in patients after myocardial infarction. Cardiology. 2009; 114: 11-8. doi: $10.1159 / 000210189$

26. Han X, Liu L, Niu J, Yang J, Zhang Z, Zhang Z. Association between VEGF polymorphisms (936c/t, -460t/c and -634g/ c) with haplotypes and coronary heart disease susceptibility. Int J Clin Exp Pathol. 2015; 8: 922-7.

27. Moradzadegan A, Vaisi-Raygani A, Nikzamir A, Rahimi Z. Angiotensin converting enzyme insertion/deletion (I/D) (rs4646994) and Vegf polymorphism (+405G/C; rs2010963) in type II diabetic patients: Association with the risk of coronary artery disease. J Renin Angiotensin Aldosterone Syst. 2015; 16: 672-80. doi: 10.1177/1470320313497819.

28. Petrovic D, Verhovec R, Globocnik Petrovic M, Osredkar J, Peterlin B. Association of vascular endothelial growth factor gene polymorphism with myocardial infarction in patients with type 2 diabetes. Cardiology. 2007; 107: 2915. doi: 10.1159/000099064.

29. Lin TH, Wang CL, Su HM, Hsu PC, Juo SH, Voon WC, Shin SJ, Lai WT, Sheu SH. Functional vascular endothelial growth factor gene polymorphisms and diabetes: effect on coronary collaterals in patients with significant coronary artery disease. Clin Chim Acta. 2010; 411: 1688-93. doi: 10.1016/j.cca.2010.07.002.

30. Gokkusu C, Cakmakoglu B, Cincin ZB, Karaagac M, Emet $\mathrm{S}$, Tamer S, Umman B. Identification of gene variants associated with hypoxia pathway in acute coronary syndrome: a pilot study. Mol Biol Rep. 2014; 41: 8055-61. doi: 10.1007/s11033-014-3703-7.
31. Janardhan B, Vaderhobli S, Bhagat R, Chennagiri Srinivasamurthy P, Venketeshiah Reddihalli P, Gawari R, Krishnamoorthy L. Investigating impact of Vascular Endothelial Growth Factor Polymorphisms in Epithelial Ovarian Cancers: A Study in the Indian Population. PLoS One. 2015; 10: e0131190. doi: 10.1371/journal. pone.0131190.

32. Churchill AJ, Carter JG, Ramsden C, Turner SJ, Yeung A, Brenchley PE, Ray DW. VEGF polymorphisms are associated with severity of diabetic retinopathy. Invest Ophthalmol Vis Sci. 2008; 49: 3611-6. doi: 10.1167/ iovs.07-1383.

33. Awata T, Inoue K, Kurihara S, Ohkubo T, Watanabe M, Inukai K, Inoue I, Katayama S. A common polymorphism in the 5'-untranslated region of the VEGF gene is associated with diabetic retinopathy in type 2 diabetes. Diabetes. 2002; 51: 1635-9.

34. Renner W, Kotschan S, Hoffmann C, Obermayer-Pietsch B, Pilger E. A common $936 \mathrm{C} / \mathrm{T}$ mutation in the gene for vascular endothelial growth factor is associated with vascular endothelial growth factor plasma levels. J Vasc Res. 2000; 37: 443-8. doi: 54076.

35. Ray D, Mishra M, Ralph S, Read I, Davies R, Brenchley P. Association of the VEGF gene with proliferative diabetic retinopathy but not proteinuria in diabetes. Diabetes. 2004; 53: 861-4.

36. Inoue $\mathrm{M}$, Itoh $\mathrm{H}$, Ueda $\mathrm{M}$, Naruko $\mathrm{T}$, Kojima A, Komatsu R, Doi K, Ogawa Y, Tamura N, Takaya K, Igaki T, Yamashita J, Chun TH, et al. Vascular endothelial growth factor (VEGF) expression in human coronary atherosclerotic lesions: possible pathophysiological significance of VEGF in progression of atherosclerosis. Circulation. 1998; 98: 2108-16. 